\title{
EFEKTIVITAS PENDIDIKAN KESEHATAN DENGAN VIDEO TENTANG PENCEGAHAN PENULARAN PENYAKIT TERHADAP PENGETAHUAN PASIEN TUBERCULOSIS DI WILAYAH KERJA PUSKESMAS SEDAU TAHUN 2019
}

\author{
Mardiatun $^{1}$, A'an Dwi Sentana ${ }^{2}$, Ilham Haqiqi ${ }^{3}$
}

\begin{abstract}
ABSTRAK
Penyakit Tuberculosis merupakan masalah kesehatan terbesar di dunia, setelah HIV (Human Immunodeficiency Virus) sehingga harus ditangani dengan serius. Tuberculosis merupakan penyakit infeksi menular yang dapat menyerang berbagai organ, terutama paru-paru. Penularan penyakit ini melalui perantaraan ludah atau dahak penderita yang mengandung basil Tuberculosis. Penularan kuman Tuberculosis dipengaruhi oleh perilaku dari pasien, keluarga serta masyarakat dalam mencegah penularan penyakit Tuberculosis. Tujuan penelitian ini adalah mengetahui efektivitas pendidikan kesehatan dengan video tentang pencegahan penularan penyakit terhadap pengetahuan pasien Tuberculosis di wilayah kerja Puskesmas Sedau. Desain penelitian ini menggunakan Pre-experimental (One group pretest-posttest). Populasi subjek dalam penelitian ini adalah pasien yang menderita Tuberculosis. Sampling penelitian ini menggunakan Purposive Sampling dan didapatkan 31 sampel, cara pengumpulan data menggunakan kuesioner dan dianalisis menggunakan uji Wilcoxon Signed Ranks Test dengan hasil $(\rho=0,000)$. Hasil penelitian ini menunjukkan sebelum diberikan pendidikan kesehatan dengan video responden memiliki pengetahuan kurang sebanyak 16 responden $(51,6 \%)$, setelah diberikan pendidikan kesehatan dengan video menjadi 30 responden $(96,8 \%)$ memiliki pengetahuan baik. Hasil penelitian didapatkan $\rho$ $(0,000)<\alpha(0,05)$ yang artinya pendidikan kesehatan dengan video tentang pencegahan penularan penyakit efektif terhadap pengetahuan pasien Tuberculosis di Wilayah Kerja Puskesmas Sedau. Diharapkan agar pihak instansi kesehatan menggunakan video yang dibuat oleh peneliti dalam memberikan pendidikan kesehatan.
\end{abstract}

Kata Kunci: Pendidikan Kesehatan dengan Video, Pengetahuan, Tuberculosis.

\section{THE EFFECT OF HEALTH EDUCATION WITH VIDEO ABOUT PREVENTION OF DISEASE TRANSMISSION ON KNOWLEDGE OF TUBERCULOSIS' PATIENT AT WORKING AREA OF SEDAU COMMUNITY HEALTH CENTER 2019}

\begin{abstract}
Tuberculosis is the largest problem in the world, after HIV (Human Immunodeficiency Virus) so that must be handled seriously. Tuberculosis is contagious disease that could infected various organs, especially the lungs. The infection is through the intercession of saliva or the patient's sputum that containing bacillus Tuberculosis. The infection of bacillus Tuberculosis is affected by the behaviour of the patient, families and commuities in preventing the infections of Tuberculosis. The purposes of this study is to know the effect of health education with video about prevention of disease transmission on knowledge of Tuberculosis' patient at Working Area of Sedau Community Healt Center. Research design was Pre-experimental (One group pretest-posttest). The subject population in this research is the patient of Tuberculosis. The sampling in this research using the Purposive Sampling and obtained 31 sample, the data collectioning of knowledge was using by
\end{abstract}


questionnaire and the analyzed using Wilcoxon Signed Ranks Test with results obtained $(\rho=0,000)$. The results shows before giving the health education with video 16 respondents $(51,6 \%)$ has sufficient knowledge, after giving the health education with video it made the 30 respondents $(96,8 \%)$ has good knowledge. The results obtained $\rho(0,000)<\alpha(0,05)$ which mean the heath education with video about prevention of disease transmission on knowledge of Tuberculosis' patient is influence the improvement of knowledge of Tuberculosis' patient at at Working Area of Sedau Community Healt Center. It is expected the health agency use the video from the researcher in giving the health education.

\section{Keywords: Health Education with Video, Knowledge, Tuberculosis}

\section{PENDAHULUAN}

Penyakit Tuberculosis merupakan masalah kesehatan terbesar di dunia, setelah HIV (Human Immunodeficiency Virus) sehingga harus ditangani dengan serius. Tuberculosis atau yang lebih dikenal dengan sebutan TBC adalah penyakit menular yang disebabkan kuman Mycobacterium tuberculosis yang masuk ke tubuh melalui pernafasan. TB merupakan penyakit infeksi menular yang dapat menyerang berbagai organ, terutama paru-paru. Risiko penularan TBC cukup besar pada kelompok orang yang tinggal di tempat tinggal yang tidak memenuhi syarat kesehatan, misalnya lingkungan padat dan kumuh, tempat pendidikan dengan asrama, rumah tahanan atau lembaga pemasyarakatan (Kemenkes RI, 2018).

Tuberculosis merupakan penyakit yang berbahaya dengan penyebaran yang cepat dan dapat membahayakan orang yang tertular. Penularan penyakit ini melalui perantaraan ludah atau dahak penderita yang mengandung basil Tuberculosis (Somantri, 2007). Penularan kuman Tuberculosis dipengaruhi oleh perilaku dari pasien, keluarga serta masyarakat dalam mencegah penularan penyakit Tuberculosis. WHO merekomendasikan strategi Directly Observed Treatment Short-course (DOTS) sebagai strategi dalam pengendalian Tuberculosis sejak tahun 1995 yang dimaksudkan untuk mengefektifkan pengobatan penderita dan menghindari penularan dari orang kontak yang termasuk subclinical infection. Namun, program penanggulangannya masih rendah sehingga prevalensi penularan penyakit Tuberculosis yang terjadi di masyarakat masih sangat tinggi. Peran serta pasien Tuberculosis sangat penting dalam mencegah penularan yang terjadi (Fitria, Mutia, 2016).

Worl Health Organization (WHO) pada tahun 2015 menyebutkan terdapat 9,6 juta kasus Tuberculosis di dunia dan 58\% kasus terjadi di daerah Afrika dan Asia Tenggara. Tiga negara dengan insidensi kasus terbanyak tahun 2015 yaitu India (23\%), Indonesia (10\%), dan China (9\%). Indonesia sekarang berada pada ranking kedua negara dengan beban Tuberculosis tertinggi di dunia (WHO, 2015). Menurut data Depkes RI tahun 2015 di Indonesia setiap tahunnya terjadi 175.000 kematian akibat Tuberculosis dan terdapat 450.000 kasus Tuberculosis, tiga per empat dari kasus Tuberculosis ini terjadi pada usia produktif (15-49 tahun), separuhnya tidak terdiagnosis dan baru sebagian yang tercakup dalam program penanggulangan Tuberculosis sesuai dengan rekomendasi WHO. 
Data Dinas Kesehatan Provinsi NTB tahun 2015 menunjukkan bahwa Provinsi NTB pada tahun 2014 dilaporkan jumlah seluruh pasien Tuberculosis (semua tipe) mencapai 6.165 orang, dan sebanyak 4.247 orang diantaranya merupakan kasus baru BTA positif, sedangkan pada tahun 2015, jumlah seluruh pasien Tuberculosis adalah 5.931 orang dengan 4.151 orang diantaranya merupakan kasus Tuberculosis BTA positif. Meski mengalami sedikit penurunan pada tahun 2015, namun bisa dikatakan penderita penyakit Tuberculosis di Provinsi NTB masih sangat tinggi (Dinkes Provinsi NTB, 2015). Tahun 2017 di Kabupaten Lombok Barat penemuan kasus suspek Tuberculosis tertinggi di Puskesmas di Kabupaten Lombok Barat terdapat di Puskesmas Sedau yaitu dengan jumlah 1.338 penderita, untuk kasus Tuberculosis BTA (+) baru sejumlah 29 penderita dan untuk kasus Tuberculosis semua tipe berjumlah 45 penderita (Dinas Kesehatan Kabupaten Lombok Barat, 2017).

Studi pendahuluan melalui wawancara dengan perawat di Puskesmas Sedau dilakukan pada tanggal 13 Oktober 2018, menyatakan bahwa pemberian pendidikan kesehatan hanya sebatas KIE (komunikasi, informasi dan edukasi) dengan ceramah saja. Selain itu, peneliti juga melakukan wawancara kepada pasien Tuberculosis yang sedang mengambil obat dan kontrol ke Puskesmas Sedau mengungkapkan bahwa pernah diberikan pendidikan kesehatan namun hanya sedikit karena diberikan secara singkat sehingga pasien masih sering melakukan kebiasaan membuang ludah di sembarang tempat, jarang memakai masker, dan masih menggunakan peralatan yang sama dengan keluarga yang lain yang tidak mengalami Tuberculosis.

Pasien dengan Tuberculosis BTA positif merupakan sumber penularan penyakit Tuberculosis. Batuk atau bersin dari pasien Tuberculosis akan menyebarkan kuman ke udara dalam bentuk droplet nuclei (percikan dahak). Beberapa faktor yang mengakibatkan menularnya penyakit itu adalah kebiasaan buruk pasien Tuberculosis yang meludah sembarangan (Anton, 2008; Currie, 2005 dalam Suharyo, 2013). Selain itu, kebersihan lingkungan juga dapat mempengaruhi penyebaran virus. Misalnya, rumah yang kurang baik dalam pengaturan ventilasi. Kondisi lembab akibat kurang lancarnya pergantian udara dan sinar matahari dapat membantu berkembangbiaknya virus (Guy, 2009; Talu, 2006 dalam Suharyo, 2013). Oleh karena itu orang sehat yang serumah dengan penderita Tuberculosis merupakan kelompok sangat rentan terhadap penularan penyakit tersebut. Lingkungan rumah, lama kontak serumah dan perilaku pencegahan baik oleh penderita maupun orang yang rentan sangat mempengaruhi proses penularan penyakit Tuberculosis. Karakteristik wilayah pedesaan, menjadi determinan tersendiri pada kejadian penyakit TB (Fortun, 2005; Mitnick, 2008, Randy, 2011 dalam Suharyo, 2013).

Keberhasilan pengobatan Tuberculosis tergantung pada pengetahuan pasien dan dukungan dari keluarga serta informasi yang telah didapatkan oleh penderita tentang upaya pencegahan penularan Tuberculosis. Tidak ada upaya dari diri sendiri atau kurangnya informasi yang diperoleh pasien akan mempengaruhi perilaku pasien untuk melakukan upaya pencegahan penularan. Apabila ini dibiarkan, dampak yang akan muncul jika penderita memiliki perilaku yang buruk adalah penularan Tuberculosis akan semakin meluas sehingga angka kejadian Tuberculosis akan semakin meningkat, 
jika ini terus terjadi maka angka kematian terus bertambah akibat penyakit Tuberculosis (Amin dan Bahar, 2007).

Menurut Andarmoyo (2015) penderita Tuberculosis membutuhkan asupan pengetahuan yang adekuat. Pendidikan kesehatan sudah selayaknya menjadi bagian penting dalam upaya pencegahan penularan Tuberculosis. Upaya pemberian pendidikan atau promosi kesehatan sangatlah penting utuk memberikan pemahaman mendasar kepada penderita Tuberculosis sehingga diharapkan bisa meminimalkan angka kejadian Tuberculosis. Penggunaan kombinasi berbagai metode dan media promosi kesehatan akan sangat membantu dalam proses penyampaian informasi kesehatan kepada masyarakat. Semakin banyak indera yang digunakan untuk menerima sesuatu pesan yang disampaikan maka semakin banyak dan jelas pula pengertian/pengetahuan yang diperoleh oleh seseorang. (Notoatmodjo, 2007).

Maulana (2009), pancaindera yang banyak menyalurkan pengetahuan ke otak adalah mata (kurang lebih $75 \%$ sampai $87 \%$ ), sedangkan $13 \%$ sampai $25 \%$, pengetahuan manusia diperoleh dan disalurkan melalui pancaindera yang lain. Media audiovisual memberikan rangsangan melalui mata dan telinga. Perpaduan saluran informasi melalui mata yang mencapai $75 \%$ dan telinga $13 \%$ akan memberikan rangsangan yang cukup baik sehingga dalam pemberian informasi akan semakin optimal.

Berdasarkan latar belakang masalah tersebut, peneliti tertarik untuk melakukan penelitian tentang efektivitas pendidikan kesehatan dengan audiovisual tentang pencegahan penyakit terhadap pengetahuan pasien Tuberculosis di wilayah kerja Puskesmas Sedau.

\section{METODE}

Penelitian ini menggunakan desain Pre-experimental (tidak ada variabel kontrol dan sampel tidak dipilih secara random) dengan rancangan one group pretest-posttest, sedangkan menurut waktu penelitian, penelitian ini termasuk penelitian cross sectional. Populasi dalam penelitian ini adalah seluruh penderita Tuberculosis yang terdata di Puskesmas Sedau pada bulan Oktober yang berjumlah 45 penderita. Sampel dalam penelitian ini adalah pasien yang mengalami Tuberculosis sebanyak 31 penderita.

\section{HASIL PENELITIAN}

Penelitian ini dilaksanakan di Wilayah Kerja Puskesmas Sedau pada tanggal 22-28 April 2019. Hasil penelitian adalah sebagai berikut:

\section{A. Karakteristik Responden}

Gambaran umum responden pada penelitian ini, dilihat berdasarkan umur, jenis kelamin, pendidikan, dan pekerjaan. 


\section{Distribusi Responden Berdasarkan Umur}

Adapun distribusi responden berdasarkan umur, yaitu:

Tabel 1. Distribusi Responden Berdasarkan Umur Responden di Wilayah Kerja Puskesmas Sedau pada tanggal 22-28 April Tahun 2019

\begin{tabular}{cccc}
\hline No. & Kategori Umur & Jumlah & Persentase \\
\hline 1. & 17-25 Tahun & 5 & 16,13 \\
\hline 2. & 26-35 Tahun & 7 & 22,58 \\
\hline 3. & 36-45 Tahun & 6 & 19,35 \\
\hline 4. & 46-55 Tahun & 10 & 32,25 \\
\hline 5. & 56-65 Tahun & 3 & 9,69 \\
\hline & Jumlah & $\mathbf{3 1}$ & $\mathbf{1 0 0}$ \\
\hline
\end{tabular}

Berdasarkan tabel 1 di atas, menunjukkan bahwa jumlah responden terbanyak adalah berumur 46-55 tahun yaitu sebanyak 10 responden $(32,25 \%)$ dan jumlah responden terendah adalah berumur 56-65 tahun sebanyak 3 responden $(9,69 \%)$.

\section{Distribusi Responden Berdasarkan Jenis Kelamin}

Adapun distribusi responden berdasarkan jenis kelamin, yaitu:

Tabel 2. Distribusi Responden Berdasarkan Jenis Kelamin Responden di Wilayah Kerja Puskesmas Sedau pada tanggal 22-28 April Tahun 2019

\begin{tabular}{clcc}
\hline No. & Jenis Kelamin & Jumlah & Persentase \\
\hline 1. & Laki-laki & 8 & 25,80 \\
\hline 2. & Perempuan & 23 & 74,20 \\
\hline & Jumlah & $\mathbf{3 1}$ & $\mathbf{1 0 0}$ \\
\hline
\end{tabular}

Berdasarkan tabel 2 di atas, menunjukkan bahwa jumlah responden terbanyak adalah berjenis kelamin perempuan yaitu sebanyak 23 responden $(74,20 \%)$.

\section{Distribusi Responden Berdasarkan Pendidikan}

Adapun distribusi responden berdasarkan pendidikan, yaitu:

Tabel 3. Distribusi Responden Berdasarkan Pendidikan Responden di Wilayah Kerja Puskesmas Sedau pada tanggal 22-28 April Tahun 2019

\begin{tabular}{cccc}
\hline No. & Tingkat Pendidikan & Jumlah & Persentase \\
\hline 1. & Pendidikan Dasar & 23 & 74,20 \\
\hline 2. & Pendidikan Menengah & 8 & 25,80 \\
\hline & Jumlah & $\mathbf{3 1}$ & $\mathbf{1 0 0}$ \\
\hline
\end{tabular}

Berdasarkan tabel 3 di atas, menunjukkan bahwa jumlah responden terbanyak memiliki tingkat pendidikan dasar yaitu sebanyak 23 reponden $(74,20 \%)$. 
4. Distribusi Responden Berdasarkan Pekerjaan

Adapun distribusi responden berdasarkan pekerjaan, yaitu:

Tabel 4. Distribusi Responden Berdasarkan Pekerjaan Responden di Wilayah Kerja Puskesmas Sedau pada tanggal 22-28 April Tahun 2019

\begin{tabular}{clcc}
\hline No. & Pekerjaan & Jumlah & Persentase \\
\hline 1. & Bekerja & 18 & 58,10 \\
\hline 2. & Tidak Bekerja & 13 & 41,90 \\
\hline & Jumlah & $\mathbf{3 1}$ & $\mathbf{1 0 0}$ \\
\hline
\end{tabular}

Berdasarkan tabel 4 di atas, menunjukkan bahwa responden terbanyak adalah berkerja yaitu sebanyak 18 responden $(58,10 \%)$.

\section{B. Hasil Penelitian}

Data tingkat pengetahuan pada saat pre test dan post test.

Tabel 5. Efektivitas Pendidikan Kesehatan dengan Video Tentang Pencegahan Penularan Penyakit Terhadap Pengetahuan Pasien Tuberculosis di Wilayah Kerja Puskesmas Sedau pada tanggal 22-28 April Tahun 2019

\begin{tabular}{ccccccc}
\hline \multirow{2}{*}{ No. } & \multirow{2}{*}{ Pengetahuan } & \multicolumn{2}{c}{ Pre Test } & \multicolumn{2}{c}{ Post Test } & \multirow{2}{*}{$\boldsymbol{\rho}$} \\
\cline { 2 - 6 } & & $\mathbf{n}$ & $\boldsymbol{\%}$ & $\mathbf{n}$ & $\boldsymbol{\%}$ & \\
\hline 1. & Kurang & 16 & 51,60 & 0 & 0,00 & \\
\cline { 1 - 6 } 2. & Cukup & 10 & 32,30 & 1 & 3,20 & \multirow{2}{*}{0,000} \\
\cline { 1 - 6 } 3. & Baik & 5 & 16,10 & 30 & 96,80 & \\
\hline & Total & 31 & 100 & 31 & 100 & \\
\hline
\end{tabular}

Hasil statistik menggunakan Uji Wilcoxon Signed Ranks Test untuk Efektivitas Pendidikan Kesehatan dengan Video Tentang Pencegahan Penularan Penyakit terhadap Pengetahuan Pasien Tuberculosis diperoleh $\rho$ adalah 0,000 atau nilai $\rho(0,000)<\alpha(0,05)$ yang berarti hipotesis $0\left(\mathrm{H}_{0}\right)$ ditolak atau hipotesis kerja $\left(\mathrm{H}_{\mathrm{a}}\right)$ diterima, yang artinya media pendidikan kesehatan dengan menggunakan video tentang pencegahan penularan penyakit efektif terhadap peningkatan pengetahuan pasien Tuberculosis.

\section{PEMBAHASAN}

Pembahasan hasil penelitian tentang Efektivitas Pendidikan Kesehatan dengan Video Tentang Pencegahan Penularan Penyakit Terhadap Pengetahuan Pasien Tuberculosis di Wilayah Kerja Puskesmas Sedau Tahun 2019 meliputi:

\section{Identifikasi Pengetahuan Pasien Tuberculosis Sebelum diberikan Pendidikan Kesehatan dengan Video Tentang Pencegahan Penularan Penyakit}

Berdasarkan hasil penelitian yang dilakukan di Wilayah Kerja Puskesmas Sedau pada 31 responden tentang pengetahuan tentang pencegahan penularan penyakit Tuberculosis menunjukkan 
bahwa sebelum diberikan pendidikan kesehatan dengan video sebanyak 16 responden $(51,6 \%)$ memiliki pengetahuan kurang. Menurut Notoatmodjo (2012), pengetahuan adalah hasil dari tahu dan ini terjadi setelah orang melakukan penginderaan terhadap suatu objek tertentu. Penginderaan terjadi melalui pancaindera manusia, yakni indera penglihatan, pendengaran, penciuman, rasa, dan raba. Sebagian pengetahuan manusia diperoleh melalui mata dan telinga. Pengetahuan dipengaruhi oleh beberapa faktor, yaitu umur, pendidikan, dan pekerjaan.

Berdasarkan hasil penelitian tentang karakteristik responden menurut umur didapatkan hasil bahwa jumlah responden terbanyak adalah berumur 46-55 tahun yaitu sebanyak 10 responden $(32,3 \%)$ dan jumlah responden terendah adalah berumur 56-65 tahun sebanyak 3 responden $(9,7 \%)$.

Menurut Cropton (1997) dalam Aulia (2013) mengatakan bahwa pada usia 46-55 tahun merupakan rentang usia lansia awal, dimana pada rentang usia ini terjadi pengurangan kemampuan responden dalam belajar dan mengingat informasi yang diperoleh. Berdasarkan data tersebut dapat dijelaskan bahwa usia juga dapat mempengaruhi pengetahuan seseorang. Hal ini sesuai dengan pernyataan Verner dan Davidson dalam Maulana (2009) bahwa adanya enam faktor yang dapat menghambat proses berpikir pada lansia awal sehingga membuat penurunan pada suatu waktu dalam kekuatan berpikir dan bekerja, selain itu juga disebutkan bahwa pengetahuan tidak didapat pada saat tua, tetapi melalui pengetahuan yang telah dimiliki sebelumnya, pengalaman sendiri, pengalaman orang lain, lingkungan dan faktor intrinsik lainnya dapat membentuk pengetahuan seseorang dalam jangka waktu yang lama dan akan tetap bertahan sampai usia tua.

Berdasarkan teori dan penelitian sebelumnya yang terkait dengan umur sejalan dengan penelitian yang dilakukan oleh peneliti karena pada masa lansia awal ini terjadi penurunan kemampuan responden dalam proses berpikir dan proses belajar. Dimana responden sebelumnya sudah beberapa kali diberikan pendidikan kesehatan tentang penyakit Tuberculosis tetapi responden sering mengatakan tidak ingat dengan informasi yang telah diberikan tersebut dan responden kurang paham dalam melakukan pencegahan penyakit sehingga kejadian Tuberculosis khususnya di Wilayah Kerja Puskesmas Sedau masih cukup banyak.

Berdasarkan hasil penelitian tentang karakteristik responden menurut pendidikan responden didapatkan hasil bahwa jumlah responden terbanyak memiliki tingkat pendidikan dasar yaitu sebanyak 23 reponden (74,2\%). Pengetahuan sangat erat hubungannya dengan pendidikan dimana diharapkan seseorang dengan pendidikan tinggi maka orang tersebut semakin luas pengetahuannya. Pengetahuan seseorang tentang suatu objek mendukung dua aspek yaitu aspek positif dan aspek negatif. Kedua aspek inilah yang akhirnya menentukan sikap seseorang terhadap obyek tertentu. Semakin banyak aspek positif dari objek yang diketahui akan menumbuhkan sikap makin positif terhadap objek tersebut (Erfandi, 2009).

Hal ini sejalan dengan penelitian yang dilakukan oleh Raditya (2013) menyatakan tingkat pendidikan sangat berpengaruh terhadap program peningkatan pengetahuan secara langsung dan tidak langsung, pada umumnya pekerja yang berpendidikan rendah mempunyai ciri sulit untuk diajak kerja 
sama dan kurang terbuka terhadap pembaharuan. Tinggi atau rendahnya pendidikan seseorang akan memberikan pengaruh terhadap pengetahuan seseorang.

Berdasarkan teori dan penelitian sebelumnya yang terkait dengan pendidikan sejalan dengan penelitian yang dilakukan oleh peneliti karena responden yang memiliki tingkat pendidikan dasar kurang terpapar informasi sehingga menyebabkan responden memiliki keterbatasan pengetahuan tentang pencegahan penularan penyakit Tuberculosis.

Berdasarkan hasil penelitian tentang karakteristik responden menurut pekerjaan responden didapatkan hasil bahwa responden terbanyak adalah berkerja yaitu sebanyak 18 responden $(58,1 \%)$. Menurut Notoatmodjo (2012) pekerjaan seseorang sangat berpengaruh terhadap proses mengakses informasi yang dibutuhkan terhadap suatu obyek. Dengan adanya pekerjaan seseorang memerlukan banyak waktu untuk menyelesaikan pekerjaan yang dianggap lebih penting, sehingga waktu yang dimiliki sedikit untuk memperoleh informasi.

Kenyataan ini sesuai dengan pernyatan Maslow yang menjelaskan bahwa kebutuhan manusia yang paling dasar harus terpenuhi terlebih dahulu sebelum orang tersebut mampu mencapai kebutuhan yang lebih tinggi tingkatnya. Pengetahuan merupakan tingkatan yang berada diatas kebutuhan dasar maka pengetahuan tidak akan berarti saat kebutuhan untuk mempertahankan hidupnya saja belum dapat terpenuhi.

Berdasarkan teori dan penelitian sebelumnya yang terkait dengan pekerjaan sejalan dengan penelitian yang dilakukan oleh peneliti karena responden yang bekerja memiliki waktu yang lebih sedikit untuk mencari informasi dan lebih mementingkan pekerjaannya daripada mencari informasi sehingga responden memiliki pengetahuan yang terbatas tentang pencegahan penularan penyakit Tuberculosis.

\section{Identifikasi Pengetahuan Pasien Tuberculosis Setelah diberikan Pendidikan Kesehatan dengan Video Tentang Pencegahan Penularan Penyakit}

Berdasarkan hasil penelitian yang dilakukan di Wilayah Kerja Puskesmas Sedau pada 31 responden tentang pengetahuan tentang pencegahan penularan penyakit Tuberculosis menunjukkan bahwa setelah diberikan pendidikan kesehatan dengan video sebanyak 30 responden $(96,8 \%)$ memiliki pengetahuan baik. Notoatmodjo (2007) mengatakan penggunaan kombinasi berbagai metode dan media promosi kesehatan akan sangat membantu dalam proses penyampaian informasi kesehatan kepada masyarakat. Semakin banyak indera yang digunakan untuk menerima sesuatu pesan yang disampaikan maka semakin banyak dan jelas pula pengertian/pengetahuan yang diperoleh oleh seseorang.

Menurut Hamtiah (2012) peningkatan pengetahuan menggunakan media audiovisual (video) lebih menarik, tidak membosankan, bergambar hidup dan mudah dipahami, seseorang lebih tertarik untuk menonton (melihat) dan mendengarkan sehingga pengetahuan seseorang menjadi lebih baik. Hal ini sejalan dengan pernyataan Maulana (2009), pancaindera yang banyak menyalurkan pengetahuan ke otak adalah mata (kurang lebih 75\% sampai 87\%), sedangkan 13\% sampai 25\%, 
pengetahuan manusia diperoleh dan disalurkan melalui pancaindera yang lain. Media audiovisual memberikan rangsangan melalui mata dan telinga. Perpaduan saluran informasi melalui mata yang mencapai $75 \%$ dan telinga $13 \%$ akan memberikan rangsangan yang cukup baik sehingga dalam pemberian informasi akan semakin optimal.

Uraian di atas menunjukkan bahwa pengetahuan responden meningkat dari pengetahuan kurang menjadi pengetahuan baik setelah mendapatkan pendidikan kesehatan dengan video tentang pencegahan penularan penyakit. Hal ini dikarenakan pemberian pendidikan kesehatan dengan media audiovisual lebih menarik, tidak membosankan, bergambar hidup dan mudah dipahami. Dimana dengan media audiovisual akan memberikan rangsangan yang cukup baik ke otak yang akan mempermudah dalam pemberian informasi kepada responden sehingga pengetahuan responden semakin baik.

\section{Menganalisa Efektivitas Pendidikan Kesehatan dengan Video Tentang Pencegahan Penularan Penyakit Terhadap Pengetahuan Pasien Tuberculosis Sebelum dan Sesudah Diberikan Intervensi}

Hasil statistik menggunakan Uji Wilcoxon untuk Efektivitas Pendidikan Kesehatan dengan Video Tentang Pencegahan Penularan Penyakit terhadap Pengetahuan Pasien Tuberculosis diperoleh $\rho$ adalah 0,000 atau nilai $\rho(0,000)<\alpha(0,05)$ yang berarti hipotesis $0\left(\mathrm{H}_{0}\right)$ ditolak atau hipotesis kerja $\left(\mathrm{H}_{\mathrm{a}}\right)$ diterima, yang artinya media pendidikan kesehatan dengan menggunakan video tentang pencegahan penularan penyakit efektif terhadap peningkatan pengetahuan pasien Tuberculosis. Hal ini sejalan dengan teori yang dikemukakan oleh Maulana (2009) bahwa semakin banyak pancaindera yang digunakan, semakin banyak dan semakin jelas pula pengetahuan yang diperoleh.

Menurut Juliantara (2009), media audiovisual (video) mengandalkan pendengaran dan penglihatan dari sasaran. penggunaan media audiovisual (video) melibatkan semua alat indera pembelajaran, sehingga semakin banyak alat indera yang terlibat untuk menerima dan mengolah informasi, semakin besar kemungkinana isi informasi tersebut dapat dimengerti dan dipertahankan dalam ingatan.

Hal ini didukung oleh hasil penelitian yang dilakukan oleh Cahya (2014) menyimpulkan bahwa pemberian pendidikan kesehatan melalui audiovisual (video) dapat meningkatkan pengetahuan dan keterampilan seseorang.

Hasil penelitian ini menunjukkan bahwa pengetahuan responden semakin baik ketika diberikan informasi melalui pendidikan kesehatan yang diberikan dengan video. Hal ini dikarenakan pemberian pendidikan kesehatan dengan media audiovisual yang melibatkan semua alat indera pembelajaran memungkkan isi dari informasi yang diberikan dapat lebih dipahami dan dimengerti dan dipertahankan dalam ingatan responden. Hal inilah yang menyebabkan responden cepat mengerti dengan informasi yang diberikan serta memiliki pengetahuan yang semakin baik. 


\section{KESIMPULAN}

Hasil analisis uji statistik Wilcoxon Signed Ranks Test untuk efektivitas pendidikan kesehatan dengan video tentang pencegahan penularan penyakit terhadap pengetahuan pasien Tuberculosis didapatkan hasil $\rho=0,000<\alpha(0,05)$ yang berarti hipotesis $0\left(\mathrm{H}_{0}\right)$ ditolak atau hipotesis kerja $\left(\mathrm{H}_{\mathrm{a}}\right)$ diterima, yang artinya pendidikan kesehatan dengan video tentang pencegahan penularan penyakit efektiv terhadap pengetahuan pasien Tuberculosis di Wilayah Kerja Puskesmas Sedau. Diharapkan agar pihak instansi kesehatan menggunakan video yang dibuat oleh peneliti dalam memberikan pendidikan kesehatan.

\section{DAFTAR PUSTAKA}

Amin, Z., Bahar, A., 2007. Tuberkulosis Paru. Dalam: Sudoyo, A., W., dkk. Buku Ajar Ilmu penyakit Dalam Jilid III. Ed 5. Jakarta: FKUI

Andarmoyo, Sulistyo. 2015. Pemberian Pendidikan Kesehatan Melalui Media Leaflet Efektif dalam Peningkatan Pengetahuan Perilaku Pencegahan Tuberkulosis Paru di Kabupaten Ponorogo. Tersedia dalam: http://eprints.umpo.ac.id/id/eprint/2031. [diakses pada 10 November 2018 pada pukul 16.45 WITA].

Cahya, Andreas Kandhi. 2014. Pengaruh Pendidikan Kesehatan Melalui Media Audiovisual Terhadap Keterampilan Penanganan Pertama Luka Bakar Pada Siswa Sekolah Menengah Pertama Negeri 7 Surakarta 2014. Skripsi, Jurusan S1 Keperawatan Sekolah Tinggi Ilmu Kesehatan Kusuma Husada Surakarta. Tersedis dalam: http://digilib.stikeskusumahusada.ac.id/download.php?id=1308. [diakses pada 15 Juni 2019 pada pukul 21.05 WITA].

Dinas Kesehatan Provinsi NTB. 2015. Profil Kesehatan Provinsi NTB. Tersedia dalam: http://www.depkes.go.id/resources/download/profil/PROFIL_KES_PROVINSI_2015/18_NT B_2015. [diakses pada 13 Oktober 2018 pada pukul 16. 20 WITA].

Erfandi. 2009. Pengetahuan Dan Faktor-Faktor Yang Mempengaruhi. Tersedia dalam: http://forbetterhealth.wordpress.com/2009/04/19/pengetahuan-dan-faktor-faktor-yangmempengaruhi. [diakses pada 8 Juni 2019 pada pukul 17. 30 WITA].

Fitria, Mutia. 2016. Hubungan Tingkat Pengetahuan tentang Tuberkulosis dengan Kepatuhan Minum Obat di Puskesmas. JIKK Vol. 7 No.1 Januari 2016: 41-45. Tersedia dalam: http://ejr.stikesmuhkudus.ac.id/index.php/jikk/article/download/125/70 [diakses pada 13 Oktober 2018 pada pukul 20.15 WITA].

Hamtiah, S. 2012. Efektivitas Media Audio Visual (Video) Terhadap Tingkat Pengetahuan Petani Ternak Sapi Perah Tentang Kualitas Susu Di Desa Indrokilo Kecamatan Ungaran Barat Kabupaten Semarang. KEMAS 1 (2) (2012) Jurnal Kesehatan Masyarakat. Tersedia dalam: http://ejournal-s1.undip.ac.id/index.php/aaj. [diakses pada 15 Juni 2019 pada pukul 20.15 WITA].

Juliantara, Ketut. 2009. Media Pembelajaran [online]. Tersedia dalam: http://www.google.co.id/Fedukasi.kompasiana.com. [diakses pada 8 Juni 2019 pada pukul 18.45 WITA].

Kemenkes RI. 2018. TBC Ada di Sekitar Kita: Kenali Gejalanya, Temukan dan Obati Sampai Sembuh. Tersedia dalam: http://www.depkes.go.id/article/view/18032600003/tbc-is-aroundus-know-the-symptoms-find-and-treat-until-healed.html. [diakses pada 13 Oktober 2018 pada pukul 17. 30 WITA]. 
Maulana, Heri D. J. 2009. Promosi Kesehatan. Jakarta: EGC.

Notoatmodjo, S. 2007. Promosi Kesehatan dan Ilmu Perilaku. Jakarta: Rineka Cipta.

Notoatmodjo, S. 2012. Metodologi Penelitian Kesehatan Edisi Revisi. Jakarta: Rineka Cipta.

Suharyo. 2013. Determinasi Penyakit Tuberkulosis Di Daerah Pedesaan. KEMAS 9 (1) (2013) 85-91 Jurnal Kesehatan Masyarakat.Tersedia dalam: http://journal.unnes.ac.id/nju/index.php/kemas. [diakses pada 10 November 2018 pada pukul 16.20 WITA].

WHO. 2015. WHO Global TB Report 2015 Excecutive Summary. Tersedia dalam: http://www.who.int/tb/data. [diakses pada 13 Oktober 2018 pada pukul 18.05 WITA]. 